\title{
Self-Sustainable off grid Electric Vehicle (EV) Charging Station with Integration of Renewable Sources
}

\author{
Pavan M N, Vijayendra V K, Shashikala M S
}

\begin{abstract}
Electric Vehicles (EV) are the world's future transport systems. With the rise in pollutions and its effects on the environment, there has been a large scale movetowards electrical vehicles. But the plug point availability for charging is the serious problem faced by the mostof Electric Vehicle consumers. Therefore, there is a definite need to move from the GRID based/connected charging stations to standalone off-grid stations for charging the Electric Vehicles. The objective of this paper is to arrive at the best configuration or mix of the renewable resources and energy storage systems along with conventional Diesel Generator set which together works in offgrid for Electric Vehicle charging. As aconclusion, by utilizing self-sustainable off-grid power generation technology, the availability of $\mathrm{EV}$ charging stations in remote localities at affordable price can be made and mainly it reduces burden on the existing electrical infrastructure.
\end{abstract}

Keywords: Renewable Energy, Battery Energy storage (BES), EV Charging Station.

\section{INTRODUCTION}

The two main \& rapidly emerging solutions now-a-days to the world energy crisis and environmental issues are:

(1)Renewable power generation,

(2) Electrification of transportation [1].

With rapidly growing energy needs, energy generation using conventional resources has cost us both financially and also environmentally. With solar radiation (insolation/irradiance) which isrenewable, inexpensive and inexhaustible source of energy,with which can certainly fulfil these rapid increasing energy demands of today with very less carbon footprint into the environment. Today, the usage of renewable energy for different kinds of consumer needs from electricity generation to electric vehicleshas resulted in reduced consumption of non-renewable energy in the world and also reduces dependency on fossil fuels. Continual and significantdevelopment of renewable energy based generation and electric vehicles in the world have broughtinmassive benefits to society.

Revised Manuscript Received on February 05, 2020.

* Correspondence Author

Pavan M N, PG Student, Energy Systems \& Management, JSS S\&T University,Mysuru.

Vijayendra V K, PG Student, Energy Systems \& Management, JSS S\&T University,Mysuru.

Shashikala M S, PG Student, Energy Systems \& Management, JSS S\&T University,Mysuru.

(C) The Authors. Published by Blue Eyes Intelligence Engineering and Sciences Publication (BEIESP). This is an open access article under the CC BY-NC-ND license (http://creativecommons.org/licenses/by-nc-nd/4.0/)

Distributed electricity energy production from renewable seems to be a better solution towards meeting the world energy problems today [2]. Hybrid systems havea advantages of higher reliability than the systems with single source. The most common type of hybrid system is Solarwind hybrid system due to the fact that availability of wind and solar energy is enormous [3]. Both Hybrid and Non Hybrid plug-in electriccars are now-a-days coming to the marketnamely,

Hybrid Cars:Toyoto make prius V, Hyundai make Sonata Hybrid, Toyota make Camry Hybrid,Lincoln make MKZ Hybrid,Ford make Fusion Energi,Chevrolet make Volt etc.

Non Hybrid Cars:Toyota Yaris iA, Hyundai Elantra Eco, Honda Fit,Toyota Camry,Mitsubishi Mirage, etc.

The electric grid is presently used for charging these Hybrid and Non Hybrid plug-in electric cars. [4].

The Electric vehicles use one or more electric motors ortraction motors for propulsion. An electric vehicle maybe powered through a collector system by DC electricityfrom self-contained batteries, EVs are not only limited to road and rail vehicles, but also electric aircraft and spacecraft. The emerging of Electrical Vehicles in urban areas depends on the quality and accessibility of charging infrastructure. Major problems will arise for charging these vehicles in rural areas where there are lot of limitations and constraints, like from the provision of generating infrastructure to the electric vehicle equipment needs.

With integration of renewable energy sources, a reliable, quality and self-sustainablepower plant can be built by combining natural components as the main potential of electrical energy sources. By combined utilization of solar energy, wind energy and small-scale DER (Distributed Energy Resources), construction of infrastructure i.e., the charging stations for Electric Vehicles can be realized in the world to support implementation of technologies of electric vehicle.

\section{POWER SYSTEM CONFIGURATION AND MODELLING.}

The block diagram of the power system configuration is shown in Fig. 1 that includes two major section, namely AC and DC sections.

DC section consists of a DC bus which is connected to a wind turbine, Solar Photo Voltaic array, a battery bank and afuel cell.

AC section consists of AC bus which has connected solar energy, wind energy and small-scale Distributed Energy Resources (Diesel generator).

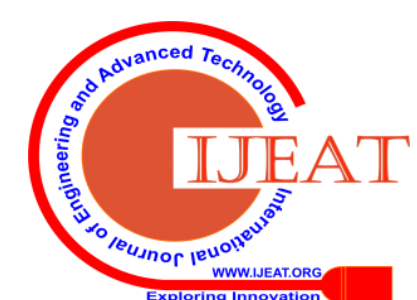


Configuration and modelling of each module will be explained in the sections below.

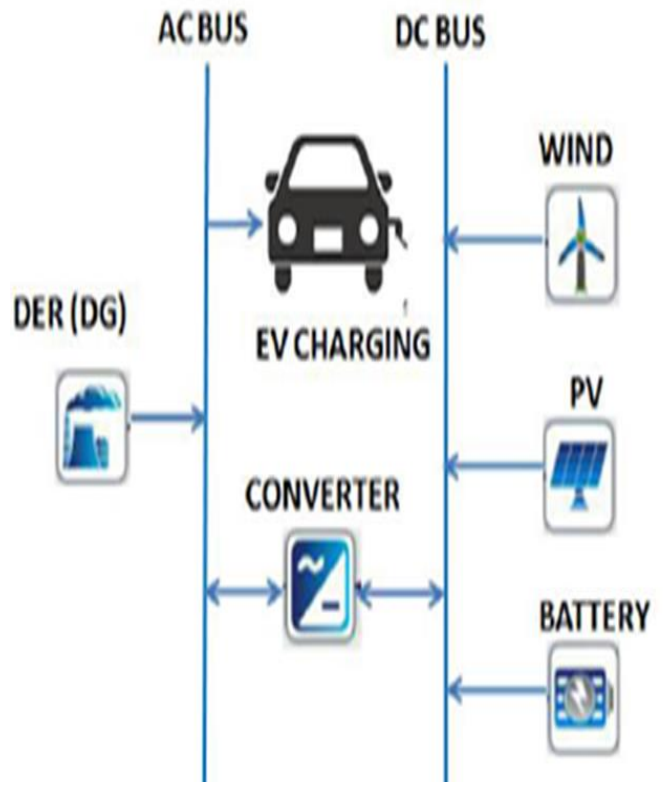

Fig1: Block diagram showingPower system configuration

\section{A. Solar PV Energy:}

Solar PV energy is the fastest growing renewable energy technology in the world and energy produced from solar PV panel depends on the solar radiation and is calculated on the basis of specifications of solar panel, such as solar panel efficiency, and the cost parameters for solar panels in accordance with local market. The following equation is used to calculate the power generated from one solar panel using hourly solar irradiation data. The following formulation is used:

$$
\mathrm{S}=\mathrm{A} * \mathrm{I} * \eta
$$

Where,

$\mathrm{S}=$ Amount of power produced by solar panel,

$\mathrm{A}=$ Area of the solar panel,

$\mathrm{I}=$ the solar panel irradiation,

$\eta=$ Efficiency of solar panel.

B. Wind Turbine:

In wind turbine, mechanical energy (recovered from the blowing wind) is used to generate electricity by using DC generator. Wind Turbines are broadly classified into two types,

(a)Vertical Axis wind turbines (VAWT)

(b) Horizontal Axis wind turbines (HAWT).

Vertical Axis wind turbines are most suitable for off grid EV Charging applications because of its proficiency to exploit wind from all direction without the need of piloting and YAW mechanism.Gyro mill type, Darries type, H-type, V-type and Savonius type are the different types of VAWT used.

The following equation is used to calculate the power generated by the wind turbine per unit swept area (W).

$$
\mathrm{W}=0.5^{*} \mathrm{Cp} * \rho^{*} \mathrm{~V} 3
$$

Where,
$\mathrm{Cp}=$ Coefficientof power which changes depending on wind speed.

$\rho=$ Air Density.

$\mathrm{V}=$ Velocity of wind.

C. Battery system:

Battery system is used in the above infrastructure for storing the surplus/excess energy from the solar PV systemsand VAWT wind energy systems. Deep-cycle lead acid battery is the most commonly used battery for this purpose because of its economy that cheaper in cost compared to the other types of batteries.

The following equation is used to calculate power output, PBat(t), expressed as a function of time [7].

$$
\text { PBat }(\mathrm{t})=\mathrm{PBat}, \mathrm{max} / \mathrm{i}(\mathrm{t}) * \mathrm{XB} * \mathrm{nB}
$$

Where,

PBat(t) is the Battery power output at time $t$.

$n B$ - total number of batteries,

PBat,max/i ( $\mathrm{t}$ ) - maximum power of battery $\mathrm{i}$ at time, $\mathrm{t}$.

XB- decision variable, discharging (1) or not discharging (0).

\section{DG system:}

In Hybrid energy systems, Diesel Generator set is used as a backup power supply. It must operate between $80-100 \%$ for getting maximum operation efficiency.In remote locations, they are sized to carry the entire loadduring all times of the day[8]. The equation for calculating energy produced from the DG setisgiven below.

$$
E D G=P D G * n_{D G}^{*} t
$$

Where,

EDG -Energy output of DG system,

PDG-Power rating of DG (KW),

nDG - efficiency of DG,

$\mathrm{t}$ - Time of operation in hours.

By parallel operation of DGs, Current capacity of the system can be increased.

\section{EV CHARGING STATION AND ITS INFRASTRUCTURE:}

EV charging station is a major element that supplies electric energy for recharging the electric vehicles. Major consideration for the people to invest and buy an Electrical vehicle largely depends on the charging stations. Charging station may be AC or DC depending on the requirement. In case of AC charging, an AC-DC converter will be placed on-board the Electrical vehicle in case of on-board charging or placed inside a charging station in case of off-board charging. In most of the literatures, this charging station is a grid connected one which is connected to the grid at all times.

In the proposed off-grid EV charging station, it is proposed to place the converter in the charging station itself with provision for both AC and DC buses in the charging station so that either AC charging or fast DC charging can be used depending on the requirement of the Electric Vehicle being charged.

A. Charging Methodology: 
Electric vehicle charging stationsare classified broadly in two types:

(a)Slow charging.

(b)Fast charging.

Sometimes, it is also classified based on its electrical charging characteristic, method of charging activity and charging period .

Slow Charging: It is used in places such as restaurants, shopping malls, business canters,railway stations, bus terminals, with fee for charging in a parking lot. It requires about two or more hours of charging and can be driven up to for 40 to $50 \mathrm{~km}$ for every hour of charging. This type of charging is also slow type and encourages users to charge while in parking.

Fast Charging: This is used in places such as highways and transport hubs. It requires about 30 minutes of charging time. The vehicle runs for about 280 to $300 \mathrm{~km}$ for every hour of charge. Capacity of battery and capability of handling rapid charging are increasing and methods of charging are required to be changed and improve for greater efficiency.

Based on the location of charging station, there are 4 different levels namely,

(a) Level 1\&2 for Residential area.

(b)Level 3 for public area.

(c)Level 4 for highway.

Charging level 1:Voltage 120/240VAC, Current 16 A, 1-phase the charging time will be 6 to 8 hours or with Voltage 400VAC,16A 3phase, charging time will be 2 to 3 hours. With $32 \mathrm{~A}$, voltage 240VAC1-phase the charging time reduced to3 to 4 hours or with voltage 400 VAC 3-phase with charging time reduced to 1 to 2 hours.

Charging level 2: Voltage 400VAC, Current63 A, 3-phase with charging time will be 20-30 minutes. At the top, charging level use voltage50-700VDC, current 100-125 A DC with less than 20 minutes of charging time. The details of different modes of charging are given in the table1:

\section{Table 1: Detailed description of modes of charging}

\begin{tabular}{|c|c|c|c|c|c|c|}
\hline Charging Mode & \multicolumn{2}{|l|}{ Mode 1} & \multicolumn{2}{|l|}{ Mode 2} & Mode 3 & Mode 4 \\
\hline Level & \multicolumn{2}{|l|}{ Level 1} & \multicolumn{2}{|l|}{ Level 2} & Level 3 & Level 4 \\
\hline Activity method & \multicolumn{2}{|l|}{ On-board } & \multicolumn{2}{|l|}{ On-board } & On-board & Off-board \\
\hline Location & \multicolumn{2}{|c|}{ Residential area } & \multicolumn{2}{|c|}{ Residential area } & Public facility & Highway / expressway \\
\hline \multirow[t]{4}{*}{ Electrical characteristic } & 1.Phase & 3.Phase & 1.Phase & 3.Phase & 3.Phase & Direct current \\
\hline & $120240 \mathrm{~V}_{\mathrm{AC}}$ & $400 \mathrm{~V}_{\mathrm{AC}}$ & $240 \mathrm{~V}_{\mathrm{AC}}$ & $400 V_{A C}$ & $400 V_{A C}$ & $50.700 \mathrm{~V}_{D C}$ \\
\hline & $16 \mathrm{~A}$ & $16 \mathrm{~A}$ & $32 \mathrm{~A}$ & $32 \mathrm{~A}$ & $63 \mathrm{~A}$ & $100-1,250 \mathrm{~A}$ \\
\hline & $3.3 \mathrm{~kW}$ & $10 \mathrm{~kW}$ & $7 \mathrm{~kW}$ & $24 \mathrm{~kW}$ & $43 \mathrm{~kW}$ & $50-300 \mathrm{~kW}$ \\
\hline Charging period & $6.8 \mathrm{~h}$ & $2.3 \mathrm{~h}$ & $3.4 \mathrm{~h}$ & $1.2 \mathrm{~h}$ & $20.30 \mathrm{~min}$ & $<20 \min$ \\
\hline
\end{tabular}

\section{B.Battery Storage System:}

The most important parameter to be considered in selecting battery for off-grid charging stations is the battery capacity (ampere-hours). Today, there are several types of batteries available the detailsof which are shown in Table 2 below.
Table 2: Comparison showing Energy storage capacity in different Batteries:

\begin{tabular}{lcccc}
\hline & $\begin{array}{c}\text { Specific } \\
\text { energy } \\
(\mathrm{Wh} / \mathrm{kg})\end{array}$ & $\begin{array}{c}\text { Life } \\
\text { cycle }\end{array}$ & $\begin{array}{c}\text { Energy } \\
\text { efficiency } \\
(\%)\end{array}$ & $\begin{array}{c}\text { Production } \\
\text { cost } \\
(\mathrm{Rs} / \mathrm{kWh})\end{array}$ \\
\hline $\begin{array}{l}\text { Lead acid } \\
\text { Nickel-cadmium } \\
\text { (Ni-Cd) }\end{array}$ & 35 & 1000 & $>80$ & 4200 \\
$\begin{array}{l}\text { Nickel-metal hydride } \\
\text { (Ni-MH) }\end{array}$ & $70-95$ & 2000 & 75 & 21000 \\
$\begin{array}{l}\text { Lithium-iron sulphide } \\
\text { (FeS) }\end{array}$ & 150 & 1000 & 80 & 82500 \\
$\begin{array}{l}\text { Lithium-iron phosphate } \\
\text { (LiFePO4) }\end{array}$ & 120 & $>2000$ & $80-95$ & 24500 \\
$\begin{array}{l}\text { Lithium-ion polymer } \\
\text { (LiPo) }\end{array}$ & $130-225$ & 2000 & $80-95$ & 10500 \\
$\begin{array}{l}\text { Lithium-ion } \\
\text { Lithium-titanate } \\
\text { (LiTiO/NiMnO2) }\end{array}$ & $118-250$ & 2000 & $>95$ & 10500 \\
\hline
\end{tabular}

A lead-acid battery is the cheapest and most commonly used battery for the electric vehicle. When weight is of least concern, the use of this battery is more recommended. The main disadvantage is that it is not environmental friendly either during production or disposal process.

There are many types of nickel based batteries which also have their own advantage and disadvantage.

Nickel-zinc battery has a advantage that it is more environmental friendly but it has a short life cycle. Disadvantages of Nickel-iron battery are high maintenance cost, heavy weight and high self-discharge rate. Nickelcadmium battery has a main disadvantage of not suitable for high charge/discharge rate like in automobile application. Others drawbacks of $\mathrm{Ni}-\mathrm{Cd}$ are they contains toxic materials and high maintenance cost. The advantage of Ni-Cd is that theyperformvery well under rigorous working conditions.

In spite of above all, Lithium battery is the one of the promising batteries that can be used as energy storage devices. Lithium battery has advantages of high specific power, light weight, high energy density, high specific energy and do not have poisonous metals like lead, mercury or cadmium. Its high production cost is the main disadvantage. Lithium battery pack consists of a protection circuit that isrequired in order to maintain safe operation.

In lithium based battery, Lithium-sulphur battery has low weight with higher energy capacity. But, it has low life cycle. Lithium metal has disadvantage of being very costlyand lesser safe compare to lithium-ion battery.

Lithium iron phosphate batteries have higher conductivity and high power density compare to Lithium-ion polymer which has a poor conductivity and also power density. Being faster to charge than other lithium-ion batteries is the main advantage of lithium-titanate battery. Thecharacteristics expected of battery charger are:

(a) Should limit the Charging current.

(b) Should Avoidovercharging of the battery by cutting-off the supply after reaching of the set state-of-charge threshold. 


\section{DRAWBACKS WITH GRID CONNECTED EV CHARGING STATIONS WHICH ARE ADDRESSED IN OFFGRID CHARGING:}

A. Voltage Stability:

The stability issue would be obvious under higher loading conditions. It results in reduced voltage depends on the capacity of grid generators and distribution network. Increase in EV plug-in stations may lead to rapid change in voltage stability, which affects generator voltage, line losses, transformer tappings, load losses.

\section{B. Peak Load Demand:}

The increased grid connected EV charging stations results in hike in the demand for power during peak time along with decreased reserve capacity.

\section{Harmonic Injection:}

Higher the number of Electric vehicles plugged into the grid, it behaves variably than its actual working. The load of EV Charging Station are particularly nonlinear in nature which may give rise to change in system current, resulting in temperature rise, reduced transformer winding insulation and malfunctioning of circuit breaker.

\section{Transformer Overloading:}

Large number of EV Charging Station adversely affects the transformers in distribution network. They reduce the lifespan of transformers. EV Charging Station connection to distribution network alters the shape of transformer load profile[6].

\section{IMPORTANT CHALLENGES WITH OFFGRID AND ITS SOLUTIONS:}

\section{A. Load profile study:}

To effectively manage with the design problems related to off grid power system, anin-depth load profile study of case study area is of prime importance. This study will help us to uncover variations in power demand during different periods of the days, months as well as seasons.

A detailed and appropriate load survey to balance between the energy demand and supply with optimum cost control is the requirement for design of hybrid system for off-grid location.

\section{B. System sizing and configuration:}

For designing and implementing of an off grid EV charging system, the main two problems linking are:

(a)System Sizing

(b)Optimal system configuration.

Both Sizing and optimization in design of EV off-grid hybrid system are mutually exclusive criteria for reducing the cost involvedand so as to ensure that the load energy needs are fully covered. The sizing of the components and the control approach must be suitably analysed and selected during the designing of an offgrid hybrid system [5].

C. Software application for simulation and optimization:
Many available software packages are used for simulation and optimization task to determine the nature of input data characteristics and the task.So, development of standard software which can perform with various natures of input data characteristics is the need of time.

\section{PROPOSED WORK:}

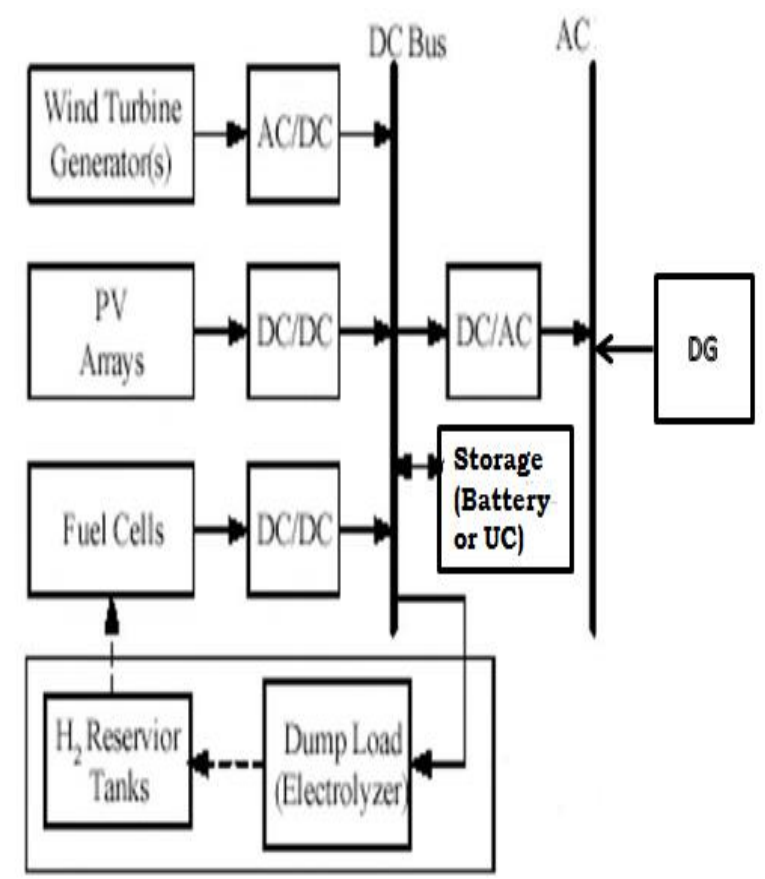

Fig 2: Block diagram showing the EV Charging System with RE integration

The two proposed works are

a) Integration of Fuel cell technology

b) Storage options with ultra-capacitors
A. Integration of Fuel Cell Technology:

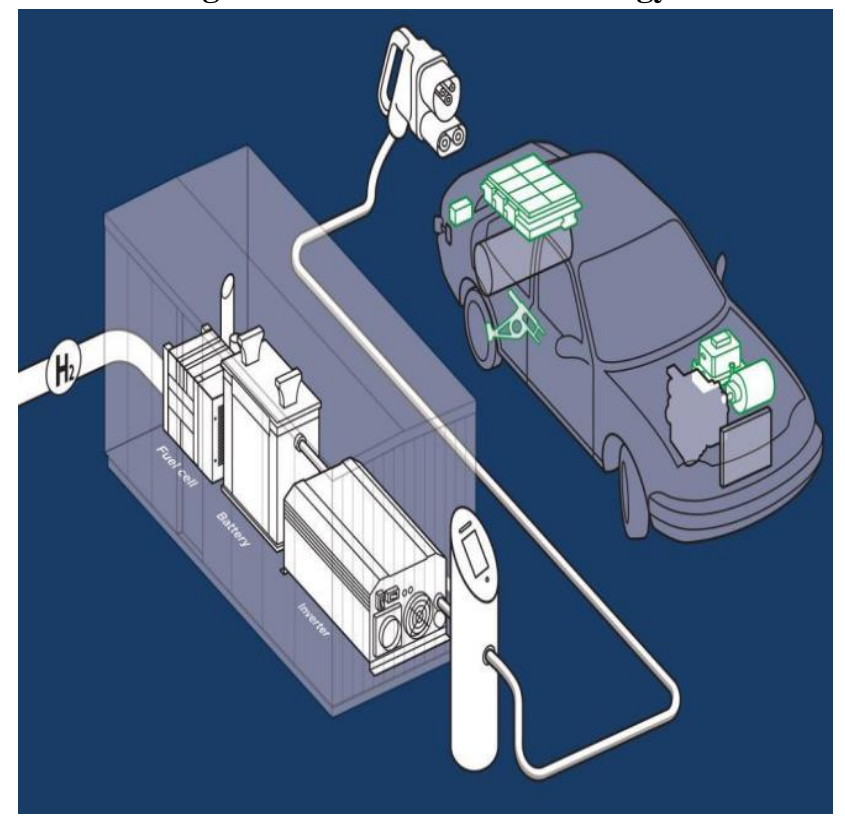

Fig 3: Fuel Cell technology Integration in EV charging.

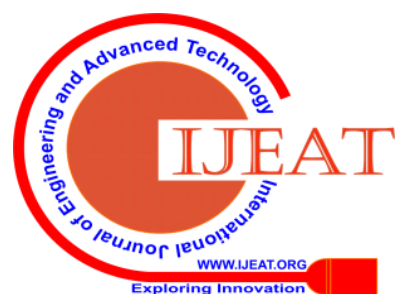


Fuel Cell technology Integration in EV charging is depicted as in Fig.3.A Device used to convert chemical potential energy i.e., energy stored in molecular bonds into electrical energy is called fuel cell. The most commonly used fuel cell technology now-a-days is Hydrogen fuel cell, in which Hydrogen and oxygen gases are used as input fuel and water ,heat and electricity are the output of the reaction in the cell. As oxygen (O2)is easily and abundant in the atmosphere, we only need to supply the fuel cell with only hydrogen (H2) which can come from an electrolysis process.

The chemical reaction that takes paces in the fuel cell is given below:

Cathode reaction: $\mathrm{O} 2+4 \mathrm{H}++4 e-\rightarrow 2 \mathrm{H} 2 \mathrm{O}$

Anode reaction: $2 \mathrm{H} 2 \rightarrow 4 \mathrm{H}++4 e-$

Overall reaction: $2 \mathrm{H} 2+\mathrm{O} 2 \rightarrow 2 \mathrm{H} 2 \mathrm{O}$

The idea is to charge battery in electric vehicles with a system based on hydrogen thus becoming independent from the grid. Naturally, it enables a mobile charging solution.

Hydrogen stored in tanks on site can be used by the fuel cell to charge the $40 \mathrm{~kW}$ batteries which then delivers its energy to the electric vehicle.

Benefits of using Fuel cell technology in EV Charging stations are:

(a) Higher efficiency compares to conventional energy sources.

(b) No Greenhouse gases will be emitted.

(c) Operates silently/ noise free.

(d) Operating time much longer than batteries.

(e) No memory effect like batteries.

(f) Maintenance is simple due to absence of moving parts.

B. Storage options with Ultra Capacitors:

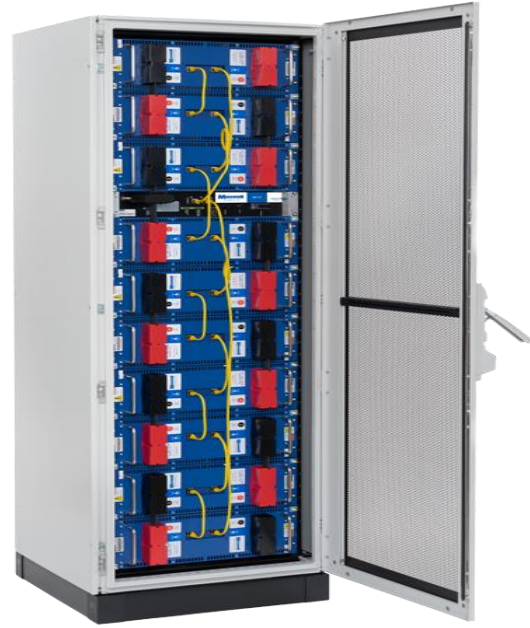

Fig 4: Storage options using Ultra Capacitors

Ultracapacitor (UC) hasstructure similar to that of a normal capacitor, difference being in the capacity,that is Ultra capacitors have high capacitance about 20 times more than that of anormal capacitor. The characteristics of ultracapacitor includes long operating cycle life, maintenancefree operation, and not sensitive to temperature variation.

Currently, Ultra Capacitortechnologies are of three types, that is,

(1)Electric Double-Layer Capacitors (EDLC), (2) pseudocapacitors and

(3)Hybrid capacitors.
The difference is in their energy storage mechanisms and their electrode materials used. The specific power density for above three types of Ultra Capacitors is almost similar and is around $1,000-2,000 \mathrm{~kW} / \mathrm{kg}$ for $95 \%$ efficient pulse but EDLC has a more power density. Specific energy density of EDLC is the lowest $(5-7 \mathrm{Wh} / \mathrm{kg})$ and the other two types of Ultra Capacitorshave energy density of 10 - 15 Wh/kg.

The Ultra Capacitor has a lifetime of 40 years, which is the longest among all knownenergy storage systems. Research conducted has compared aboveultra-capacitors and concluded that the use of pseudo-capacitance as being rare because such devices are not presently commercially available. EDLC is the best option available for offgridapplications.

Benefits of using Ultra Capacitors for storage compare to battery storage are:

(a) They have very fast charging time nearly 1000 times that of a battery of similar capacity.

(b) They have wide range of operating temperatures.

\section{COMPARATIVE ANALYSIS OF OFF-GRID AND GRID CONNECTED EV CHARGING STATION:}

1. Initial construction cost: Off- Grid charging stations have higher initial cost when compared to grid connected stations as off-grid charging required higher investment for storage devices.

2. Operational cost: Off-grid charging stations have lower operational cost since energy charges need not be paid to the utilities.

3. Reliability: Off-grid charging station improve the quality and reliability and mitigate the effect of power failure as it does not depend on the vagaries of the grid system.

4. Security: As off-grid systems are completely isolated, they are not at all prone to the grid attacks and ensure complete security of the system.

5. Power quality: Harmonics in the interconnected system will not affect the off-grid system and power quality can be maintained by proper selection of off-grid system components.

\section{CONCLUSION:}

To meet the loads of the future power system, to reduce the emission of carbon and save the environment, renewable and clean energy resources can be the better fuel of choice. The electrification of the transportation using the conventional grid connected stationsreduces the benefits of Electric Vehicle, and it may potentially increase the level of carbon emission as compared to the fossil fuel based vehicular system. Hence, to take full benefit of EVs in the real meaning, there is need for charging system which is entirely based on renewable energy sources (RES) like solar $\mathrm{PV}$, wind.

In this paper, the proposed charging station micro grid model for off-grid EV charging station with integration of renewables like Solar PV, Wind turbine, Fuel Cell with provision for storage with mainly battery and optional storage with ultra-capacitors has been presented. 
A comparative analysis of off-grid and grid connected EV charging station is made and it is observed that the off-grid charging stations would be a better choice.

\section{REFERENCES}

1. AnjeetVerma and Bhim Singh "A Solar PV, BES, Grid and DG Set Based Hybrid Charging Station for Uninterruptible Charging at Minimized Charging Cost" in 2018 IEEE Industry Applications Society Annual Meeting, IAS 2018.

2. Taha N. Gucın, KayhanInce and FilizKaraosmanoğlu "Design and Power Management of a Grid- Connected Dc Charging Station for Electric Vehicles Using Solar and Wind Power."

3. AmangaldiKoochaki, Mohammad Divandari, EbrahimAmiri and OleksandrDobzhanskyi "Optimal Design of Solar-Wind Hybrid System Using Teaching-Learning Based Optimization Applied in Charging Station for Electric Vehicles" in 2018 IEEE conference.

4. Otward M. Mueller and Eduard K. Mueller "Off-Grid, Low-Cost, Electrical Sun-Car System for Developing Countries" in IEEE 2014 Global Humanitarian Technology Conference.

5. Vijayendra VK, Pavan M N, PG students, Energy Systems \& Management, JSS S\&T University, Mysuru "An overview of Smart grid Standards and its challenges" in ICSCT 2019,Hyderbad.

6. AshwiniMathapati, MounaMachamma P M, Rangaswamy B N, Sandeep Kumar R , PG students, Energy Systems \&Management, JSS S\&T University,Mysuru "Impact Of Connecting Electric Vehicles To Grid And Its Challenges" in National Conference 2019 at GSSS,Mysuru.

7. Jabulani Mhlanga and Oliver Dzobo "Standalone hybrid energy system model and control for economic load dispatch" in 2019 SAUPEC/RobMech/PRASA Conference Bloemfontein, South Africa, January 28-30, 2019.

8. AnjeetVerma and Bhim Singh "Energy Management Strategy of Solar PV- Battery and Diesel Generator Based Electric Vehicle Charging Station" in 2018 IEEE Energy Conversion Congress and Exposition, ECCE 2018. 